\title{
KEMAMPUAN PENALARAN MATEMATIS SISWA DALAM MEMECAHKAN MASALAH ALJABAR BERDASARKAN GAYA KOGNITIF FIELD INDEPENDENT
}

\author{
Tanti Erviana \\ Pasca Sarjana Universitas Surabaya, Indonesia \\ tantierviana@mhs.unesa.ac.id
}

\begin{abstract}
:
This research aims to describe the level of mathematical reasoning ability of students with fieldindependent cognitive styles in solving algebra problems. The research method used is a qualitative descriptive approach, using qualitative data then described to produce a clear and detailed picture of students' mathematical reasoning with independent field cognitive style in solving algebra problems. The subjects of the research were Class VIII students' of SMP Negeri 47 Surabaya. The main Instrument in this study is the researchers themselves. Instrument supporters in this research is divided into 2 kinds of Tests, namely the task of problem solving algebra, and guidelines for the interview. Data collection Techniques in the study carried out using two techniques, namely written tests and interviews. The process of data analysis in this study refers to qualitative data analysis process, namely the reduction of data, presenting the data, and draw conclusions. the results of this research indicate that (1) able to conduct an investigation of the problems faced thoroughly, (2) able to plan problem solving by connecting various related information, (3) able to use the strategy chosen correctly and correctly, and (4) able to re-examine, evaluate, and draw valid conclusions based on the solution of the problem obtained. In addition, the results of this study indicate that the level of mathematical reasoning ability of students is in the category sufficient to meet the mathematical reasoning indicators of field-independent cognitive style.
\end{abstract}

Keywords: mathematical reasoning, algebra problems, cognitive styles, field independent.

\section{PENDAHULUAN}

Matematika merupakan ilmu pengetahun yang menjadi tolak ukur untuk semua mata pelajaran disekolah dasar dan menengah, karena matematika merupakan ibu dari ilmu pengetahuan lain. Hal ini sesuai dengan pendapat Carl Friedrich Gauss (Rosa, 2017) mengatakan bahwa "mathematics is the queen of sciences (matematika adalah ratunya ilmu pengetahuan)". Menurut Thalhah, Tohir, Nguyen, Shankar, \& Rahim, (2019) mengatakan bahwa "in healthcare field math plays a vital role. For diagnose, treat medical problems and presentation reliable calculations and data are must obtained by medical providers". Menurut Sujono (2001) menyatakan bahwa matematika mempunyai peranan penting dalam penguasaan ilmu pengetahuan dan teknologi. Pelajaran matematika bertujuan agar siswa memiliki sikap rasa ingin tahu, perhatian, pantang menyerah, dan minat dalam mempelajari matematika serta sikap ulet dan percaya diri dalam pemecahan masalah.

Adapun materi pelajaran matematika diajarkan di sekolah menengah pertama meliputi teori bilangan, aljabar, geometri, aritmatika, dan statistika 
(As'ari, Tohir, Valentino, Imron, \& Taufiq, 2017). Materi aljabar merupakan materi dasar matematika untuk mempelajari materi-materi matematika lainnya. Menurut Tohir (2017) materi aljabar merupakan materi yang menjadi dasar dari semua materi matematika, karena hampir setiap soal matematika selalu menggunakan konsep aljabar yang biasa digunakan adalah huruf/simbol $x$ yang mewakili nilai dari suatu bilangan yang ingin dicari. Menurut Erviana (2019) kesulitan yang dialami siswa dalam memecahkan masalah aljabar sangatlah beragam, ada yang merasa kesulitan dalam menghitung dan ada juga yang merasa kesulitian dalam menghubungkan suatu permasalahan untuk diselesaikan baik yang bersifat tekstual maupun bersifat kontekstual. Sedangkan berdasarkan hasil penelitina yang didapat oleh Rizta, Zulkardi, \& Hartono (2013) menunjukkan bahwa salah satu faktorpenyebab rendahnya penalaran siswa karena soal-soal yang diberikan guru dalampembelajaran matematika lebih menekankan ke pemahaman konsep, sedangkan soal-soalyang menuntut kemampuan berpikir tingkat tinggi termasuk bernalar secara matematis jarang dilatihkan. Hal ini diperjelas oleh Tohir (2017) mengatakan bahwa bahwa kemampuan penalaran matematis merupakan proses berfikir secara logis dan matematis dalam menarik suatu kesimpulan baik secara induktif maupuan deduktif berdasarkan pengetahuan yang didapat sebelumnya atau secara tiba-tiba dalam menemukan suatu kebenaran.

Pada prinsipnya hambatan dalam belajar tak mungkin dapat dipungkiri keberadaannya, namun setidaknya hal tersebut dapat diminimalisir dengan kemampuan penalaran yang dimiliki siswa. Hambatan belajar terjadi salah satunya karena perbedaan gaya kognitif siswa. Pengajaran matematika di kelas sekolah yang tidak disesuaikan dengan gaya kognitif siswa cenderung tidak dapat memberikan pengetahuan secara utuh kepada siswa, sehingga mengakibatkan penalaran matematis siswa menjadi lemah dan hasil belajar mereka tidak optimal. menurut Kogan (Slavin, 2008) mengatakan bahwa salah satu perbedaan individu dalam gaya kognitif adalah dalam hal kebergantungan lapangan (field dependent) dan ketidak bergantungan lapangan (field independent). Menurut Keefe (Wooldridge \& Haimes-Bartolf, 2006) mengatakan bahwa field dependent/independent mengukur sejauh mana seorang individu menggunakan "sebuah analisis yang bertentangan terhadap cara global/umum dari pengalaman lingkungan sekitar".

Hasil penelitian yang dilakukan oleh (Tohir, 2017) menunjukkan bahwa tingkat kemampaun penalaran matematis siswa kelompok tinggi rata-rata berada pada kategori "terpenuhi" dan mampu memberikan penjelasan terhadap yang ditulis/dikerjakan, siswa kelompok sedang rata-rata berada pada kategori "cukup terpenuhi" dan mampu memberikan penjelasan terhadap yang ditulis/dikerjakan, akan tetapi belum lengkap, dan siswa kelompok rendah rata-rata berada pada kategori "kurang terpenuhi" dan tidak mampu memberikan penjelasan terhadap yang ditulis/dikerjakan. Adapun hasil penelitian yang dilakukan oleh Sumartini (2015) menunjukkan bahwa untuk mengetahui peningkatan kemampuan penalaran matematis siswa sebagai akbiat dari pembelajaran berbasis masalah dan pembelajaran konvensional. Hasil penelitian didapat bahwa kemempuan penalaran matematis siswa yang mendapat pembelajaran berbasis masalah lebih baik daripada siswa yang mendapat pembelajaran konvensional. Sedangkan hasil penelitian yang dilakukan oleh Erviana (2019) menunjukkan bahwa subjek

Alifmatika: Jurnal Pendidikan dan Pembelajaran Matematika, Desember 2019, Vol. 1, No. 1 
merencanakan dengan cara mempresentasikan pernyataan dalam soal menjadi simbol persamaan aljabar, kemudian mencari hubungannya dan memilih teknik penyelesaian eliminasi yang dianggap sesuai dan cepat langsung mengarah kepada yang ditanyakan soal. Oleh karena itu, maka tujuan penelitian ini adalah untuk mendeskripsikan tingkat kemampuan penalaran matematis siswa dalam memecahkan masalah aljabar apabila di rinjau dari gaya kognitif field independent.

\section{METODE PENELITIAN}

Jenis penelitian yang digunakan pada penelitian ini adalah penelitian deskriptif dengan pendekatan kualitatif. Data kualitatif yang didapat, kemudian dideskripsikan untuk menghasilkan gambaran yang jelas dan terperinci tentang penalaran matematis siswa Kelas VIII SMP Negeri 47 Surabaya dalam memecahkan masalah aljabar ditinjau dari daya kognitif field independent. Penelitian kualitatif memiliki ciri-ciri yaitu mempunyai latar belakang alamiah (konteks dari suatu keutuhan), manusia sebagai alat atau instrumen, menggunakan metode kualtitatif, analisis data secara induktif, penyusunan teori berdasarkan data, data bersifat deskriptif, lebih mementingkan proses dari pada hasil, adanya batas yang ditentukan oleh fokus, adanya kriteria khusus untuk keabsahan data, desain bersifat sementara, dan hasil penelitian merupakan hasil keputusan bersama (Tohir, Susanto, Hobri, Suharto, \& Dafik, 2018; (Tohir \& Wardani, 2016).

Ada dua instrumen yang digunakan dalam penelitian ini yaitu instrumen utama dan instrumen pendukung. Instrumen utama dalam penelitian ini adalah peneliti sendiri. Peneliti terlibat sendiri dalam proses merencanakan, memilih subjek penelitian, melaksanakan pengumpulan data melalui tugas pemecahan masalah dan wawancara yang merupakan data utama dalam mendeskripsikan penalaran matematis siswa dalam memecahkan masalah aljabar, menganalisis data, menafsirkan data dan membuat data membuat kesimpulan. Peneliti harus objektif dan netral, sehingga sifat kealamiahan data terjaga. Menganalisis data penelitian berarti melakukan proses pengaturan data, pengolahan data, dan penyajian data penelitian untuk mebuat suatu kesimpulan (Maswar, 2017). Sedangkan, Instrumen pendukung dalam penelitian ini terbagi atas 3 macam, yaitu tes penggolongan gaya kognitif, tes tugas pemecahan masalah aljabar, dan pedoman wawancara.

Teknik pengumpulan data dalam penelitian ini dilakukan dengan menggunakan dua teknik yaitu tes tertulis dan wawancara. Tes tertulis berisi soalsoal materi perpangkatan dan penfaktoran digunakan untuk mendeskripsikan profil penalaran matematis siswa dalam memecahkan masalah aljabarditinjau dari gaya kognitif Field Independent. Wawancara dilakukan untuk memperoleh data yang lebih jelas tentang profil penalaran matematis siswa ditinjau dari gaya kognitif Field Independent. Subjek penelitian yang telah terpilih akan diberikan sejumlah pertanyaan berkenaan dengan alasan mengapa mereka menjawab soal tes tertulis sebagaimana yang tertera di dalam lembar jawabannya. Jawaban ini akan menimbulkan pertanyaan berikutnya sampai diperoleh informasi yang lengkap untuk menggambarkan profil penalaran matematis siswa terkait dengan menghitung perpangkatan dan penfaktoran aljabar. Oleh karena itu format wawancara dibuat sefleksibel mungkin (tidak terstruktur).

Alifmatika: Jurnal Pendidikan dan Pembelajaran Matematika, Desember 2019, Vol. 1, No. 1 
Kemudian, data yang dikumpulkan melalui tes tertulis dan wawancara tersebut diuji keabsahannya dengan triangulasi. Triangulasi merupakan usaha mengecek kebenaran data atauinformasi yang diperoleh oleh peneliti dari berbagai sudut pandang berbeda dengan cara mengurangi sebanyak mungkin bias yang terjadi pada saat pengumpulan data dan analisis data. Analisis dilakukan setelah proses pemberian tes tertulis, kemudian hasil tes tertulis akan dijadikan acuan dalam membuat pedoman wawancara. Analisis data dilakukan untuk mengungkap profil penalaran matematis siswa dengan gaya kognitif field independent dalam memecahkan masalah aljabar. Proses analisis data dalam penelitian ini mengacu pada proses analisa data kualitatif, yaitu mereduksi data, menyajikan data, dan menarik kesimpulan.

Adapun indikator yang digunakan untuk mengetahui tingkat kamampuan penalaran matematis siswa dalam memecahkan masalah aljabar dapat dilihat pada Tabel 1 berikut:

Tabel 1 Kategori Indikator Penalaran Matematis

\begin{tabular}{ll}
\hline \multicolumn{1}{c}{$\begin{array}{c}\text { Kategori Penalaran } \\
\text { Matematis }\end{array}$} & \multicolumn{1}{c}{ Indikator Penalaran Matematis } \\
\hline $\begin{array}{l}\text { Step one: a problematic } \\
\text { situation is met } \\
\text { (situasi bermasalah) }\end{array}$ & $\begin{array}{l}\text { Menyadari bahwa soal / masalah tugas dapat atau } \\
\text { tidak dapat diselesaikan / dijawab }\end{array}$ \\
$\begin{array}{l}\text { Step two: strategy choise } \\
\text { (pemilihan strategi) }\end{array}$ & $\begin{array}{l}\text { Memilih / mengingat kembali / menyusun / } \\
\text { menemukan / menebak strategi pemecahan }\end{array}$ \\
$\begin{array}{l}\text { Step three: } \\
\text { implementation } \\
\text { (implementasikan } \\
\text { strategi) }\end{array}$ & $\begin{array}{l}\text { Melaksanakan strategi yang sudah dipilih (strategi } \\
\text { penyelesaian) }\end{array}$ \\
$\begin{array}{l}\text { Step four: conclusions } \\
\text { (penyimpulan) }\end{array}$ & Menyatakan hasil pemecahan/penyelesaian \\
\hline
\end{tabular}

Sedangkan untuk mengetahui kemampuan bernalar siswa dilakukan dengan cara merekapitulasi setiap nomor soal tes kemampuan penalaran matematis. Kriteria skor untuk soal tes tingkat kemampaun penalaran matematis pada penelitian ini dapat disajikan pada tabel 2 berikut. 
Tabel 2 Kriteria Tingkat Kemampuan Penalaran Matematis Siswa

\begin{tabular}{cl}
\hline Kategori & \multicolumn{1}{c}{ Kriteria } \\
\hline $\begin{array}{c}\text { Tingkat 4 } \\
\text { (Sangat Terpenuhi) }\end{array}$ & $\begin{array}{l}\text { Semua indikator penalaran matematis siswa sangat } \\
\text { terpenuhi dengan jelas atau sangat lengkap } \\
\text { berdasarkan keempat kategori penalaran matematis }\end{array}$ \\
Tingkat 3 & $\begin{array}{l}\text { Semua indikator penalaran matematis siswa terpenuhi } \\
\text { dengan jelas atau lengkap berdasarkan keempat } \\
\text { kategori penalaran matematis }\end{array}$ \\
Tingkat 2 & $\begin{array}{l}\text { Semua indikator penalaran matematis siswa cukup } \\
\text { terpenuhi dengan jelas atau cukup lengkap berdasarkan } \\
\text { keempat kategori penalaran matematis }\end{array}$ \\
(Cukup Terpenuhi) & $\begin{array}{l}\text { Semua indikator penalaran matematis siswa kurang } \\
\text { terpenuhi dengan jelas atau kurang lengkap } \\
\text { berdasarkan keempat kategori penalaran matematis }\end{array}$ \\
(Kurang Terpenuhi) & Semua indikator penalaran matematis siswa tidak \\
terpenuhi dengan jelas atau tidak lengkap berdasarkan & keempat kategori penalaran matematis
\end{tabular}

Diadaptasi dari Mohammad Tohir (2017)

\section{PEMBAHASAN}

Hasil penelitian dapat diperoleh berdasarkan gambaran atas kemampuan penalaran matematis siswa dalam memecahkan masalah aljabar berdasarkan gaya kognitif Field Independent dapat diuraikan sebagai berikut.

Tugas Pemecahan Masalah Aljabar 1(TPMA-1)

Diketahui umur Raka sekarang adalah 5 tahun lebih tua dari umur Dinda sekarang. Jika jumlah umur keduanya adalah 45 tahun, berapakah umur Raka 10 tahun yang akan datang?

Berikut ini adalah petikan wawancara terhadap siswa gaya kognitif field independent dalam merencanakan penyelesaian masalah aljabar berdasarkan TPMA-1.

Peneliti: Dapatkah Bella memecahkan soal aljabar ini?

Siswa : Emmm, sebentar saya baca dan pahami dulu Bu

Peneliti: Bagamaimna Bella, apakah kamu bisa?

Siswa : Iya Bu, saya bisa.

Peneliti: Oke.. apa yang kamu ketahui tentang soal tersebut?

Siswa : Umur Raka 5 tahun lebihnya dari umur Dinda, Jumlah umur mereka 45 tahun, emmm kemudian ditanyakan umur Raka 10 tahun akan datang. 


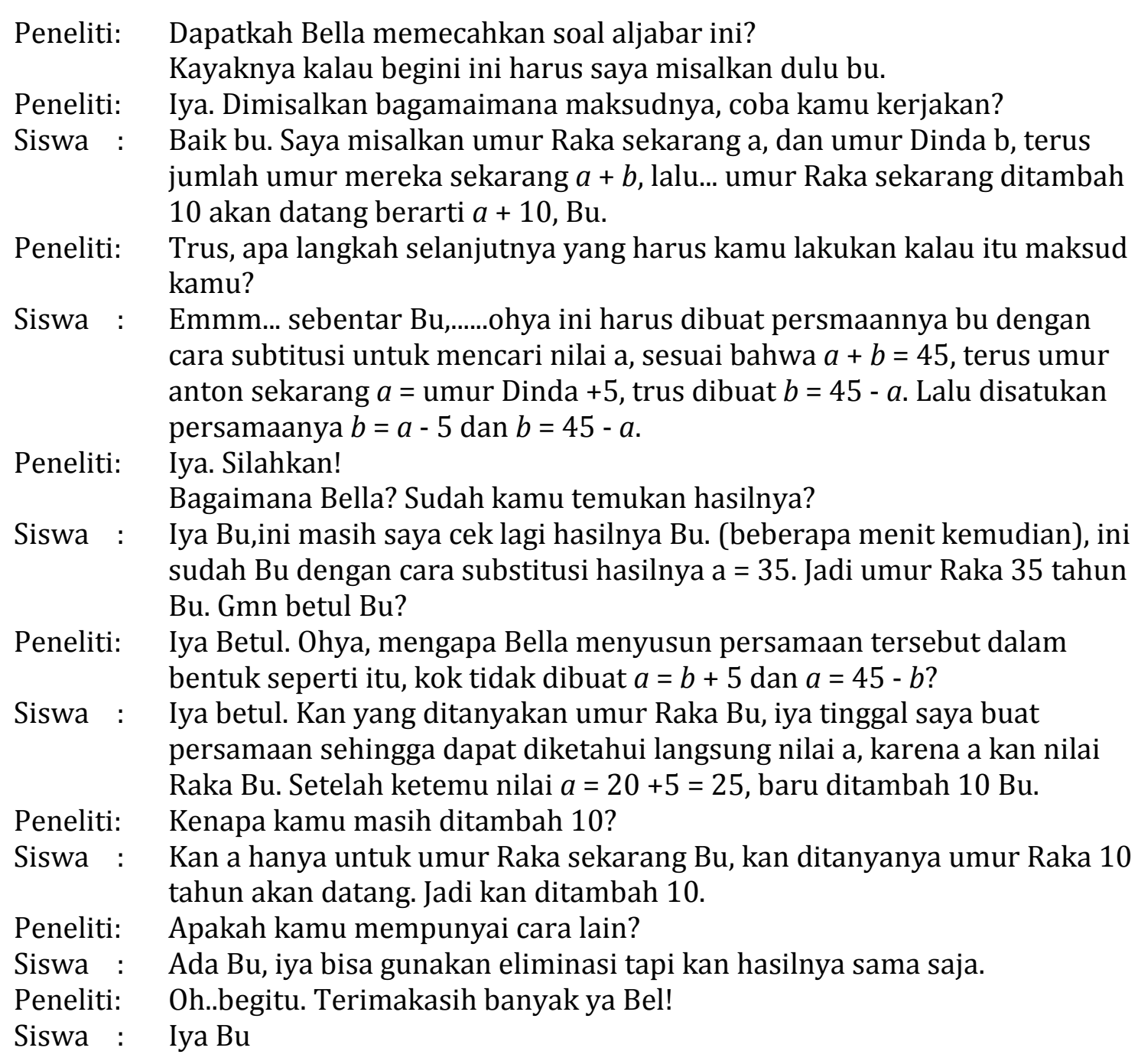

Berdasarkan kutipan wawancara di atas terhadao siswa field independent dalam merencanakan penyelesaian masalah sebagai berikut.

1) Siswa field independent menganalisa permasalahan pada soal terlebihdulu sebelum memutuskan bisa atau tidak memecahkan soal tersebut. dalam hal ini berarti siswa field independent telah melakukan investigasi terhadap soal dengan cara memahami soal untuk menemukan apa yang diketahui, apa yang ditanyakan dan teknik penyelesaian yang dapat digunakan.

2) Siswa field independent mempresentasikan pernyataan dalam soal menjadi simbol persamaan aljabar yaitu dengan memisalkan umur Raka sekarang a, dan umur Dinda $\mathrm{b}$, terus jumlah umur mereka sekarang $a+b$, lalu... umur Raka sekarang ditambah 10 akan datang berarti $a+10$ dan selanjutnya ia mencari hubungannya

3) Siswa field independent menyusun pemecahan soal dalam bentuk persamaan dan memecahkannya menggunakan cara substitusi. Siswa field independent memilih strategi penyelesaian dengan menganalisa jawaban yang mengarah kepada pertanyaan, sehinga dalam penyusunan persamaannya siswa field independent langsung mencari nilai a tidak nilai $b$. 


\section{Tanti Erviana}

4) Siswa field independent melakukan penarikan kesimpulan dengan menetapkan hasil yang ia peroleh yaitu umur Raka 10 tahun yang akan datang adalah 35 . Meskipun demikian, siswa field independent tidak langsung yakin dengan jawabannya, ia melakukan pengeceekan ulang dan meminta pendapat peneliti soal kebenaran dari jawabannya

Tugas Pemecahan Masalah Aljabar 2(TPMA-2)

Diketahui umur Andy sekarang adalah 3 tahun lebih muda dari umur Yanti sekarang. Jika jumlah umur keduanya adalah 31 tahun, berapakah umur Yanti 5 tahun yang akan datang?

Peneliti: Dapatkah Bella memecahkan soal aljabar ini?

Siswa : $\quad$ Emmm, kayaknya saya bisa Bu, saya pahami dulu ya Bu.

Peneliti: $\quad$ Oke. (Beberapa menit kemudian), apakah Bella bisa memecahkan soal itu?

Siswa : $\quad$ Iya $\mathrm{Bu}$, saya bisa.

Peneliti: $\quad$ Oke.. apa yang kamu ketahui tentang soal tersebut? coba kamu tuliskan dalam lembar jawaban!

Siswa : $\quad$ Baik Bu, Umur Andi 3 tahun lebih muda dari umur Yanti Bu, Jumlah umur mereka 31 tahun, emmm kemudian yang ditanyakan umur Yanti 5 tahun akan datang.

Peneliti: Trus, apa langkah kamu selanjutnya?

Siswa : Akan saya misalkan dulu, misalnya umur Andy adalah $x$ sekarang, dan trus umur Yanti y, lalu jumlah umur mereka sekarang $x+y$, sedangkan umur Andi sekarang adalah $y$ - 3 dan umur Yanti 5 tahun akan datang berarti $y+5$, Bu.

Peneliti: Trus, bagaimana pemecahannya?

Siswa : $\quad$ Emmm...saya susun persmaannya Bu lalu saya kerjakan dengan cara subtitusi untuk mencari nilai $y$, kan diketahui $x+y=31$, terus umur Andi sekarang $x=y-3$, trus dibuat $x=31-y$, selanjutnya saya satukan dan saya selesaikan persamaanya $\mathrm{Bu}$.

Peneliti: Bella, sudah kamu temukan hasilnya?

Siswa : $\quad$ Iya $\mathrm{Bu}$, kayaknya nilai $y=17$. Jadi nilai Yanti 5 tahun akan datang 17 $+5=22$.

Peneliti: $\quad$ Ohya, mengapa Bella menyusun persamaan tersebut dalam bentuk seperti itu, kok tidak dibuat $x=y-3$ dan $x=31$ - y?

Siswa : Kan yang ditanyakan umur Yanti $\mathrm{Bu}$, iya tinggal saya buat persamaan sehingga dapat diketahui langsung nilai $y$, karena $y$ kan nilai Yanti Bu. Setelah ketemu nilai y kemudian ditambah 5, sehingga ketemu $17+5=22$. Benar kan Bu?

Peneliti: Iya Benar, Apakah kamu mempunyai cara lain?

Siswa : $\quad$ Ada $\mathrm{Bu}$, iya bisa gunakan eliminasi tapi kan hasilnya sama saja.

Peneliti: Oh..begitu. Terimakasih ya Bel.

Siswa : Iya, sama-sama $\mathrm{Bu}$

Berdasarkan kutipan wawancara di atas terhadao siswa field independent dalam merencanakan penyelesaian masalah sebagai berikut.

Alifmatika: Jurnal Pendidikan dan Pembelajaran Matematika, Desember 2019, Vol. 1, No. 1 
1) Siswa field independent menganalisa permasalahan pada soal terlebihdulu sebelum memutuskan bisa atau tidak memecahkan soal tersebut. dalam hal ini berarti Siswa field independent telah melakukan investigasi terhadap soal dengan cara memahami soal untuk menemukan apa yang diketahui, apa yang ditanyakan dan teknik penyelesaian yang dapat digunakan.

2) Siswa field independent mempresentasikan pernyataan dalam soal menjadi simbol persamaan aljabar yaitu dengan memisalkan umur Andy adalah $\mathrm{x}$ sekarang, dan trus umur Yanti $y$, lalu jumlah umur mereka sekarang $x+y$, sedangkan umur Andi sekarang adalah $y-3$ dan umur Yanti 5 tahun akan datang berarti $y+5$.

3) Siswa field independent menyusun pemecahan soal dalam bentuk persamaan dan memecahkannya menggunakan cara substitusi. SFI memilih strategi penyelesaian dengan menganalisa jawaban yang mengarah kepada pertanyaan, sehinga dalam penyusunan persamaannya siswa field independent langsung mencari nilai y tidak nilai $\mathrm{x}$

4) Siswa field independent melakukan penarikan kesimpulan dengan menetapkan hasil yang ia peroleh yaitu umur Yanti 5 tahun yang akan datang adalah 22 . Meskipun demikian, siswa field independent tidak langsung yakin dengan jawabannya, ia melakukan pengeceekan ulang dan meminta pendapat peneliti soal kebenaran dari jawabannya

Kemudian, untuk menguji kevalidan data terhadap hasil wawancara siswa field independent dalam merencanakan penyelesaian masalah pada TPMA-1 dan TPMA2 di atas dilakukan triagulasi waktu, yaitu mencari kesesuaian data wawancara TPMA-1 dengan TPMA-2. Adapun triagulasi waktu TPMA-1 dan TPMA-2 dapat dilihat pada Tabel 3 berikut ini.

Tabel 3 Triagulasi Penalaran Matematis Siswa field independent dalam Memecahkan Masalah Aljabar

\begin{tabular}{|c|c|}
\hline Data Pada TPMA-1 & Data Pada TPMA-2 \\
\hline $\begin{array}{l}\text { Siswa field independent menganalisa } \\
\text { permasalahan pada soal terlebihdulu } \\
\text { sebelum memutuskan bisa atau tidak } \\
\text { memecahkan soal tersebut. dalam hal } \\
\text { ini berarti siswa field independent telah } \\
\text { melakukan investigasi terhadap soal } \\
\text { dengan cara memahami soal untuk } \\
\text { menemukan apa yang diketahui, apa } \\
\text { yang ditanyakan dan teknik } \\
\text { penyelesaian yang dapat digunakan. } \\
\text { Siswa field independent } \\
\text { mempresentasikan pernyataan dalam } \\
\text { soal menjadi simbol persamaan aljabar } \\
\text { yaitu dengan memisalkan umur Raka } \\
\text { sekarang } a \text {, dan umur Dinda } b \text {, terus } \\
\text { jumlah umur mereka sekarang } a+b, \\
\text { lalu... umur Raka sekarang ditambah }\end{array}$ & $\begin{array}{l}\text { Siswa field independent menganalisa } \\
\text { permasalahan pada soal terlebihdulu } \\
\text { sebelum memutuskan bisa atau tidak } \\
\text { memecahkan soal tersebut. dalam hal } \\
\text { ini berarti siswa field independent telah } \\
\text { melakukan investigasi terhadap soal } \\
\text { dengan cara memahami soal untuk } \\
\text { menemukan apa yang diketahui, apa } \\
\text { yang ditanyakan dan teknik } \\
\text { penyelesaian yang dapat digunakan. } \\
\text { Siswa field independent } \\
\text { mempresentasikan pernyataan dalam } \\
\text { soal menjadi simbol persamaan aljabar } \\
\text { yaitu dengan memisalkan umur Andy } \\
\text { adalah } x \text { sekarang, dan trus umur Yanti } \\
y \text {, lalu jumlah umur mereka sekarang } x \\
+y \text {, sedangkan umur Andi sekarang }\end{array}$ \\
\hline
\end{tabular}

Alifmatika: Jurnal Pendidikan dan Pembelajaran Matematika, Desember 2019, Vol. 1, No. 1 


\begin{tabular}{|c|c|}
\hline Data Pada TPMA-1 & Data Pada TPMA-2 \\
\hline $\begin{array}{l}10 \text { akan datang berarti } a+10 \text { dan } \\
\text { selanjutnya ia mencari hubungannya. } \\
\text { Siswa field independent menyusun } \\
\text { pemecahan soal dalam bentuk } \\
\text { persamaan dan memecahkannya } \\
\text { menggunakan cara substitusi. Siswa } \\
\text { field independent memilih strategi } \\
\text { penyelesaian dengan menganalisa } \\
\text { jawaban yang mengarah kepada } \\
\text { pertanyaan, sehinga dalam } \\
\text { penyusunan persamaannya siswa field } \\
\text { independent langsung mencari nilai } a \\
\text { tidak nilai } b \text {. } \\
\text { Siswa field independent melakukan } \\
\text { penarikan kesimpulan dengan } \\
\text { menetapkan hasil yang ia peroleh yaitu } \\
\text { umur Raka } 10 \text { tahun yang akan datang } \\
\text { adalah } 35 \text {. Meskipun demikian, siswa } \\
\text { field independent tidak langsung yakin } \\
\text { dengan jawabannya, ia melakukan } \\
\text { pengeceekan ulang dan meminta } \\
\text { pendapat peneliti soal kebenaran dari } \\
\text { jawabannya. }\end{array}$ & $\begin{array}{l}\text { adalah y - } 3 \text { dan umur Yanti } 5 \text { tahun } \\
\text { akan datang berarti } y+5 \text {. } \\
\text { Siswa field independent menyusun } \\
\text { pemecahan soal dalam bentuk } \\
\text { persamaan dan memecahkannya } \\
\text { menggunakan cara substitusi. Siswa } \\
\text { field independent memilih strategi } \\
\text { penyelesaian dengan menganalisa } \\
\text { jawaban yang mengarah kepada } \\
\text { pertanyaan, sehinga dalam } \\
\text { penyusunan persamaannya siswa field } \\
\text { independent langsung mencari nilai y } \\
\text { tidak nilai } x \text {. } \\
\text { Siswa field independent melakukan } \\
\text { penarikan kesimpulan dengan } \\
\text { menetapkan hasil yang ia peroleh yaitu } \\
\text { umur Yanti } 5 \text { tahun yang akan datang } \\
\text { adalah } 22 \text {. Meskipun demikian, siswa } \\
\text { field independent tidak langsung yakin } \\
\text { dengan jawabannya, ia melakukan } \\
\text { pengeceekan ulang dan meminta } \\
\text { pendapat peneliti soal kebenaran dari } \\
\text { jawabannya. }\end{array}$ \\
\hline
\end{tabular}

Triagulasi waktu di atas, terlihat bahwa data SFI dalam memahami hingga membuat kesimpulan dari pemecahan masalah (TPMA-1 dan TPMA-2) cenderung analitis dan konsisten. Cenderung analitis yang dimaksud ialah merencanakan pemecahan dengan teliti dan sistematis sesuai dengan apa yang ditanyakan pada soal, padahal strategi pemecahan soal tersebut sangatlah variatif. Sedangkan konsisten yang dimaksud dalam penelitian ini ialah ada kesesuaian antara data TPMA-1 dan TPMA-2, yang memenuhi indikator-indikator penalaran matematis siswa dalam merencanakan pemecahan masalah aljabar.

Dengan demikian terbukti bahwa data penalaran matematis siswa field independent dalam merencanakan pemecahan masalah aljabar adalah valid, sehingga dapat disimpulkan data kemampuan penalaran matematis siswa field independent dalam memecahkan masalah aljabar sebagai berikut.

a) Siswa field independent menganalisa permasalahan yang dihadapi secara matang untuk dapat memecahkannya dengan mudah. Dalam hal ini berarti siswa field independent telah melakukan investigasi terhadap soal dengan cara memahami soal terlebih dahulu untuk menemukan apa yang diketahui, apa yang ditanyakan dan bagaimana teknik pemecahan yang dapat digunakan secara efektif dan efisien.

b) Siswa field independent merencanakan pemecahan soal yang dihadapi dengan cara mempresentasikan pernyataan dalam soal menjadi simbol persamaan aljabar, kemudian ia mencari hubungannya dan memilih teknik penyelesaian 
yang dianggap sesuai dan cepat langsung mengarah kepada yang ditanyakan soal tersebut.

c) Siswa field independent memecahkan soal menggunakan cara substitusi yang telah ia pilih. Siswa field independent memilih strategi penyelesaian ini didasarkan pada analisa ia sebelumnya, karena strategi ini dianggap dapat memecahkan masalah pada soal sesuai dengan yang ditanyakan. Dan terbukti hasil perhitungan langsung mengarah pada substansi permasalahan.

d) Siswa field independent melakukan penarikan kesimpulan dengan menetapkan hasil pemecahan yang ia peroleh. Meskipun demikian, siswa field independent tidak langsung yakin dengan jawabannya, ia melakukan pengecekan ulang dan untuk memastikan bahwa hasil pemecahannya benar sesuai dengan yang ditanyakan pada soal. Salah satu hal yang dilakukan ialah siswa field independent meminta pendapat peneliti soal kebenaran dari hasil pemecahannya.

Berdasarkan uraian diatas, maka siswa yang memiliki gaya kognitif Field Independent dalam memecahkan masalah aljabar memiliki nilai rata-rata sangat baik dalam melaksanakan perhitungan matematis. Hal ini sesuai dengan hasil penelitian Annur, Sujadi, \& Subanti (2016) menunjukkan bahwa siswa dengan field independent terlihat lebih lancar, lebih cepat dalam pengerjaan dan memunculkan jawaban yang sudahia yakini kebenarannya. Menurut Ngilawajan (2013) juga menyatakan bahwa siswa dengan field independent tidak terlalu sulit dalam memisahkan informasi yang esensial dari konteksnya dan lebih selektif dalam menyerap informasi yang diterima.

Sedangkan berdasarkan hasil analisis dalam penelitian ini didapat tentang tingkat gaya kognitif siswa field independent dalam memecahkan masalah aljabar berdasarkan capaian kategori indikator penalaran matematis secara umum dapat dilihat pada tabel 4 berikut.

Tabel 4 Tingkat Kemampuan Penalaran Matematis Siswa

\begin{tabular}{ccc}
\hline Kategori & $\begin{array}{c}\text { Data Tingkat Kemampuan Penalaran Matematis } \\
\text { Jumlah }\end{array}$ & $\begin{array}{c}\text { Persentase (\%) } \\
\text { Pumpat 4 }\end{array}$ \\
\hline $\begin{array}{c}\text { Tingkat } \\
\text { (Sangat Terpenuhi) } \\
\text { Tingkat 3 } \\
\text { (Terpenuhi) } \\
\text { Tingkat 2 } \\
\text { (Cukup Terpenuhi) } \\
\text { Tingkat 1 } \\
\text { (Kurang Terpenuhi) } \\
\text { Tingkat 0 } \\
\text { (Tidak Terpenuhi) }\end{array}$ & 4 & 24 \\
\hline
\end{tabular}

Berdasarkan data yang disajikan pada Tabel 4, secara keseluruhan menunjukkan bahwa tingkat kemampuan penalaran matematis siswa berada pada kategori tidak terpenuhi sebanyak 2 siswa (8\%), ada sebanyak 3 siswa (12\%) berada pada kategori kurang terpenuhi, ada sebanyak 10 siswa (40\%) berada pada

Alifmatika: Jurnal Pendidikan dan Pembelajaran Matematika, Desember 2019, Vol. 1, No. 1 


\section{Tanti Erviana}

kategori cukup terpenuhi, ada sebanyak 7 siswa (24\%) berada pada kategori terpenuhi, dan ada sebanyak 4 siswa (16\%) berada pada kategori sangat terpenuhi. Oleh karena itu, siswa dengan gaya kognitif field independent tidak selalu memiliki kemampuan penalaran matematis yang sama. Hal ini sesuai dengan hasil penelitian yang didapat oleh Khoiriyah (2013) menunjukkan bahwa kategori subjek dengan gaya kognitif yang sama tidak selalu memiliki tingkat berpikir yang sama pula. Adapun berdasarkan hasil penelitian yang didapat oleh Tohir (2017) menunjukkan bahwa berdasarkan hasil analisa tingkat kemampaun penalaran matematis siswa kelompok tinggi rata-rata berada pada kategori "terpenuhi" dan mampu memberikan penjelasan terhadap yang ditulis/dikerjakan, siswa kelompok sedang rata-rata berada pada kategori "cukup terpenuhi" dan mampu memberikan penjelasan terhadap yang ditulis/dikerjakan, akan tetapi belum lengkap, dan siswa kelompok rendah rata-rata berada pada kategori "kurang terpenuhi" dan tidak mampu memberikan penjelasan terhadap yang ditulis/dikerjakan. Sedangkan berdasarkan hasil penelitian yang didapat oleh Akramunnisa (2017) menyimpulkan bahwa subjek yang bergaya kognitif field independent kemampuannya dalam menyelesaikan masalah terurut, jelas dan analitis. Hal ini sejalan dengan hasil penelitian Andriyani (2018) yang menyimpulkan bahwa subjek yang bergaya kognitif field independent dalam memecakan masalah sering melakukan kesalahan teknik yaitu salah perhitungan dan menulis nilai akhir. Hal ini dipertehas oleh Soekamto (Tohir, 2019) mengatakan bahwa seseorang dapat melupakan informasi yang telah diperoleh karena ia gagal untuk merubah ingatan jangka pendek menjadi ingatan jangka panjang karena kurang adanya pengulangan atau karena dia tidak dapat mengelompokkan informasi yang diperolehnya. Oleh karena itu, perlu adanya pembelajaran matematika dengan menggunakan model permbelajaran yang bervariatif untuk membantu meningkatkan kemampuan penalaran matematis siswa secara kontinu dan berkesinambungan.

\section{KESIMPULAN DAN SARAN}

Berdasarkan hasil penelitian dan pembahasan yang telah diuraikan di atas, makadapat disimpulkan bahwa: (1) Siswa field independent dapat menemukan permasalahan yang dihadapi. Siswa field independent menganalisa soal secara matang untuk dapat memecahkannya dengan mudah. Ia melakukan investigasi terhadap soal dengan cara memahami soal terlebih dahulu untuk menemukan apa yang diketahui, apa yang ditanyakan dan bagaimana teknik pemecahan yang dapat digunakan secara efektif dan efisien; (2) Siswa field independent memilih strategi pemecahan masalah yang dihadapi, subjek SFI menganalisa permasalahan secara rinci dan mereppresentasikan seluruh data pada soal kedalam bentuk simbol dan menyusunnya kedalam bentuk persamaan dua variabel, kemudian ia mencari hubungannya dan memilih teknik penyelesaian yang dianggap sesuai dan cepat langsung mengarah kepada yang ditanyakan soal tersebut; (3) siswa field independent melaksanakan strategi pemecahan yang telah dipilih yakni substitusi. SFI melakukannya secara rinci didasarkan pada analisa ia sebelumnya, karena strategi ini dianggap dapat memecahkan masalah pada soal sesuai dengan yang ditanyakan. Dan terbukti hasil perhitungan langsung mengarah pada substansi

Alifmatika: Jurnal Pendidikan dan Pembelajaran Matematika, Desember 2019, Vol. 1, No. 1 
permasalahan; (4) Siswa field independent membuat kesimpulan dengan cara menetapkan hasil pemecahan yang ia peroleh. Meskipun demikian, siswa field independent tidak langsung yakin dengan jawabannya, ia melakukan pengecekan ulang dan untuk memastikan bahwa hasil pemecahannya benar sesuai dengan yang ditanyakan pada soal. Salah satu hal yang dilakukan ialah siswa field independent meminta pendapat peneliti soal kebenaran dari hasil pemecahannya; dan (5) Kemampuan penalaran matematis siswa terdapat pada pada kategori cukup memenuhi indikator penalaran matematis siswa. Hal ini disebabkan karena karakteristik kemampuan penalaran matematika pada masing-masing siswa mempunyai perbedaan yang signifikan dan berlatar belakang sekolah yang berbeda juga. Adapaun faktor-faktor yang mempengaruhi kemampuan penalaran matematis siswa antara lain ketelitian dalam memahami dan menyelesaikan soalsoal test, kecenderungan siswa dalam mengandalkan hafalan, tiruan dan motivasi. Sedangkan untuk mengembangkan kemampuan penalaran matematis siswa antara lain dapat ditempuh dengan mengembangkan pengetahuan yang telah didapat sebelumnya, mengerjakan soal-soal yang berbentuk pemecahan masalah secara kontinu seperti soal TIMSS dan PISA, dan membaca soal dengan cermat sehingga kemampuan dalam memahami, menginformasikan, memilih strategi, mengevaluasi, dan menganalisis pemecahan masalah akan semakin lebih baik lagi.

\section{DAFTAR RUJUKAN}

Akramunnisa, A. S. (2017). Ability Analysis Based on Math Problem Completing The Early Math Skills and Cognitive Style on Class VIII SMPN 13 Makassar. Jurnal Daya Matematis, 5(1), 14.

Andriyani, A. (2018). Analisis Kesalahan Siswa dalam Menyelesaikan Soal Cerita pada Materi Program Linear Ditinjau dari Gaya Kognitif Siswa. Pendekar: Jurnal Pendidikan Berkarakter, 1(1), 16-22.

Annur, M. F., Sujadi, I., \& Subanti, S. (2016). Aktivitas Metakognisi Siswa Kelas X SMAN 1 Tembilahan dalam Pemecahan Masalahan Matematika Ditinjau dari Gaya Kognitif. Jurnal Pembelajaran Matematika, 4(7).

As'ari, A. R., Tohir, M., Valentino, E., Imron, Z., \& Taufiq, I. (2017). Buku Guru Matematika (Revisi). Jakarta: Pusat Kurikulum dan Perbukuan, Balitbang, Kemendikbud.

Erviana, T. (2019). Penalaran Siswa SMP dengan Gaya Kognitif Field Dependent dalam Memecahkan Masalah Aljabar. Prosiding Silogisme, 1(1).

Khoiriyah, N. (2013). Analisis Tingkat Berpikir Siswa Berdasarkan Teori Van Hiele pada Materi Dimensi Tiga Ditinjau dari Gaya Kognitif Field Dependent Dan Field Independent (Penelitian Dilakukan di SMA Negeri 1 Mojolaban Kelas X Tahun Ajaran 2011/2012).

Maswar. (2017). Analisis Statistik Deskriptif Nilai UAS Ekonomitrika Mahasiswa dengan Program SPSS 23 \& Eviews 8.1. Jurnal Pendidikan Islam Indonesia, 1(2), 273-292. https://doi.org/10.35316/jpii.v1i2.54

Ngilawajan, D. A. (2013). Proses berpikir siswa SMA dalam memecahkan masalah 


\section{Tanti Erviana}

matematika materi turunan ditinjau dari gaya kognitif field independent dan field dependent. PEDAGOGIA: Jurnal Pendidikan, 2(1), 71-83.

Rizta, A., Zulkardi, Z., \& Hartono, Y. (2013). Pengembangan Soal Penalaran Model TIMSS Matematika SMP. Jurnal Penelitian Dan Evaluasi Pendidikan, 17(2), 230-240.

Rosa, E. (2017). Pengaruh Penerapan Model Pembelajaran Matematika Knisley (MPMK) Menggunakan Media Petak Warna-Warni Terhadap Kemampuan Pemahaman Matematis Siswa Dalam Pembelajaran Segitiga di Kelas VII MTs. Putra-Putri Simo. INSPIRAMATIKA: Jurnal Inovasi Pendidikan Dan Pembelajaran Matematika, 3(1), 43-52.

Slavin, R. E. (2008). Educational psychology: Theory and practice (Terjemahan Marianto Samosir). Jakarta: PT Indeks.

Sujono. (2001). Pengajaran Matematika Untuk Sekolah Menengah. Jakarta: Depdikbud P2LPTK.

Sumartini, T. S. (2015). Peningkatan Kemampuan Penalaran Matematis Siswa Melalui Pembelajaran Berbasis Masalah. Mosharafa: Jurnal Pendidikan Matematika, 4(1), 1-10.

Thalhah, S. Z., Tohir, M., Nguyen, P. T., Shankar, K., \& Rahim, R. (2019). Mathematical Issues in Data Science and Applications for Health care. International Journal of Recent Technology and Engineering, 8(2S11), 41534156. https://doi.org/10.35940/ijrte.B1599.0982S1119

Tohir, M. (2017). Pengembangan Bahan Ajar Olimpiade Matematika Berdasarkan Model Pemecahan Masalah untuk Meningkatkan Kemampuan Penalaran Matematis Siswa. In Tesis. Magister Pendidikan Matematika Universitas Jember. https://doi.org/10.13140/RG.2.2.31121.79200

Tohir, M. (2019). Peningkatan Kompetensi Guru Pembina Olimpiade Matematika Siswa Sekolah Menengah Pertama Kabupaten Madiun. As-Sidanah: Jurnal Pengabdian Masyarakat, 1(2), 199-226. https://doi.org/10.35316/assidanah.v1i2.587

Tohir, M., Susanto, Hobri, Suharto, \& Dafik. (2018). Students' Creative Thinking Skills in Solving Mathematics Olympiad Problems Based on Problem-Solving Polya and Krulik-Rudnick Model. Advanced Science Letters, 24(11), 83618364. https://doi.org/10.1166/asl.2018.12563

Tohir, M., \& Wardani, A. (2016). Analysis of Prospective Mathematics Teachers Ability in Applying Scientific Approach Based The Curriculum 2013. Proceedings of The National Seminar on Mathematics Education, 431-446. https://doi.org/10.13140/RG.2.2.35316.09603

Wooldridge, B., \& Haimes-Bartolf, M. (2006). The field dependence/field independence learning styles: Implications for adult student diversity, outcomes assessment and accountability. Learning Styles and Learning, 237257. 